\title{
THE “DISINHERITED” DAUGHTER AND THE DISAPPROVING MOTHER
}

MELITA Jackson died in 2004, leaving an estate worth $£ 486,000$. In 2002 , she had made a will in which she left a $£ 5,000$ legacy to the BBC Benevolent Fund and divided the remainder of her estate between the Blue Cross, the Royal Society for the Protection of Birds, and the Royal Society for the Prevention of Cruelty to Animals ("the Charities"). Mrs. Jackson had also written a letter of wishes in which she explained her decision to exclude her only daughter, Heather, from her will. Heather had left home in 1978 at the age of 17, without her mother's knowledge or agreement, in order to live with Mr. Ilott, whom Heather later married. Mrs. Jackson clearly disapproved of her daughter's choice of lifestyle. Heather and her husband had five children (the last one living at home, being due to go to university in 2015) and lived in straitened financial circumstances. For example, Heather never went on holiday, found it difficult to afford clothes for the children and a range of food, and possessed many items that were old or second-hand. Despite attempts at reconciliation, mother and daughter were estranged for some 26 years, and Heather was fully aware before Mrs. Jackson's death that she was due to be excluded from the will.

Heather initiated proceedings under the Inheritance (Provision for Family and Dependants) Act 1975, claiming that her mother's will failed to make "reasonable financial provision" for her maintenance (s. 1). The litigation has a long history. In 2007, Judge Million agreed with Heather's contention, and exercised his discretion to hold that she should receive $£ 50,000$ from the estate (an extract from the judgment appears in an annex to Ilott $v$ Mitson [2015] EWCA Civ 797). Eleanor King J. held ([2009] EWHC 3114 (Fam)) that Judge Million had erred in finding that the will had failed to make reasonable financial provision. The Court of Appeal overturned King J.'s decision ([2011] EWCA Civ 346), remitting Heather's appeal on quantification to the High Court. Parker J. upheld the $£ 50,000$ award ([2014] EWHC 542 (Fam)). Heather then appealed again, seeking a greater share of the estate, and her appeal was allowed ([2015] EWCA Civ 797).

Giving judgment on the case for the second time in the Court of Appeal, Arden L.J. (with whom Ryder L.J. and Sir Colin Rimer agreed) identified two "fundamental errors" in Judge Million's approach (at [35]). The first was the fact that the judge stated that the award should be "limited" because of the applicant's lack of expectation of provision and her ability to live within her current means, but wrongly omitted to explain "what the award might otherwise have been and to what extent it was limited by the matters in question" (at [35]). The second error was the judge's failure to verify what effect his award would have on the 
applicant's entitlement to state benefits, simply assuming that a large capital payment (even including the one he made) would disentitle the family to most if not all of their benefits.

In light of those errors, the Court of Appeal proceeded to exercise the discretion afresh, considering the factors set out in s. 3 in relation to the facts as they stood at the time of its own judgment. In doing so, Arden L.J. noted that the Charities did not have any relevant resources or needs and that anything they received from the estate was a windfall. In addition, they were not held to have any expectation of such a benefit, since Mrs. Jackson had had no involvement with them during her lifetime.

While Arden L.J. accepted that Heather was an adult child living independently - a relevant factor meaning "at a minimum" that the court was "not concerned to provide her with an income that would fully support her needs" (at [49]) - Arden L.J. also agreed that Heather's current standard of living was not conclusive regarding the appropriate level of maintenance, and reaffirmed that an adult child did not need to show a moral obligation or other special circumstance in order to succeed. The absence of an expectation of inheritance on her part was not to be given "much weight", since Arden L.J. upheld Judge Million's finding that Heather "was deprived of any expectation primarily because Mrs. Jackson had acted in an unreasonable, capricious and harsh way towards her only child" (at [51](iii)).

In response to conflicting submissions from Heather and the Charities on the weight that should be attached to Mrs. Jackson's testamentary intentions, Arden L.J. concluded that Parliament had "entrusted the courts with the power to ensure, in the case of even an adult child, that reasonable financial provision is made for maintenance only", and that this limitation itself gave appropriate weight to testamentary freedom at least in cases where the other claimants on the estate have no demonstrated need or expectation (at [51](v)). She later accepted, however, the need to balance claims on the estate "fairly" (at [60]), albeit surprisingly suggesting that the Charities were "not prejudiced" by a higher award (at [61]). Arden L.J. refused to hold that the estrangement should eliminate or substantially diminish an appropriate award. There was no suggestion that Heather had wanted to be estranged from Mrs. Jackson, Heather's disapproved lifestyle choices had nevertheless allowed her to become a successful mother and homemaker, and fault for the estrangement was difficult to apportion and might even have been absent.

In evaluating Heather's needs and resources, Arden L.J. noted the absence of any savings and her limited income and earning capacity, the latter being something that could only have diminished since Judge Million's original decision. Even including her state benefits, it was held that Heather's resources were "at such a basic level that they outweigh the importance 
that would normally be attached to the fact that [she] is an adult child who had been living independently for so many years" (at [57]). Having earlier recognised that the size of the estate did not "impinge" on the award sought (at [50]), and aiming to preserve the family's state benefits, Arden L.J. ultimately concluded that Heather should receive $£ 143,000$ to enable her to purchase the housing association property in which she and her family were living, in addition to the reasonable costs of the purchase. Heather was also given an option to claim up to $£ 20,000$ as a capital sum from the estate, in order to provide "a very small additional income to supplement her state benefits" (at [63]).

The Court of Appeal's judgment caused a stir in some quarters (not least to the Comment Editor of the Daily Telegraph on 28 July 2015). It might be construed as an attack on the core principle of testamentary freedom, particularly if it limits the extent to which testamentary intentions should be specifically evaluated against reasonable financial provision. That said, the decision stops very far short of introducing the kind of "forced heirship" associated with civil law jurisdictions (see e.g. C. Castelein, R. Foqué, and A. Verbeke (eds.), Imperative Succession Law in a Late-Modern Society (Antwerp 2009)).

It must also be borne in mind that, throughout the life of the 1975 Act, it has been a calculated risk to "disinherit" children who might need maintenance in the future (cf. spouses and civil partners, whose valid claims are not limited to maintenance: 1975 Act, s. 1(2)(a)(aa)), and that the deceased's views and intentions have always been somewhat relevant to, but obviously not conclusive of, the appropriate level of provision (see e.g. R. Kerridge, Parry and Kerridge: The Law of Succession, 12th ed. (London 2009), para. [8-31]). Ilott confirms those contentions, but it is by no means the most dramatic case in which provision has been made for an adult child. In Re Land (deceased) [2006] EWHC 2069 (Ch), for example, an adult son successfully claimed provision from his mother's estate notwithstanding his conviction for her gross negligent manslaughter and the resulting application of the forfeiture rule (Forfeiture Act 1982, s. 1) to his share under her will. Moreover, neither disapproval of lifestyle (Espinosa $v$ Bourke [1999] 1 F.L.R. 747 (CA)) nor estrangement (Gold v Curtis [2005] W.T.L.R. 673 (Ch)) has inevitably prevented claims in previous cases.

While Ilott does not therefore represent a sea change in the law, the portion of the estate awarded to Heather was considerable (albeit that her need was relatively high) and the case may provide pause for thought to solicitors advising clients who wish to exclude adult children from their wills, particularly in favour of non-natural persons such as charities. If it is thought that testators in England and Wales should be freer to "disinherit" such children than Mrs. Jackson turned out to be, legislative reform is likely to be necessary. Significantly, however, 
the Law Commission's most recent report to consider the 1975 Act (Intestacy and Family Provision Claims on Death (Law Com 331, 2011), at [6.2]-[6.26]) recommended no such change on this matter and appeared to assume that any reform would be in the direction of facilitating increased rather than decreased provision for adult children in any event.

BRIAN SLOAN

Robinson College, Cambridge, CB3 9AN, UK. Email: bds26@cam.ac.uk 